\title{
Potential drug interactions analysis of COVID-19 patients at a hospital in West Java
}

\section{Analisis potensi interaksi obat pada pasien rawat inap COVID-19 pada suatu rumah sakit di Jawa Barat}

\author{
Larasati Arrum Kusumawardani ${ }^{1}$, Nisa Maria ${ }^{1 *}$, Yumna Nabila Fanani $^{1}$ \\ 1Laboratorium Farmasi Klinik dan Farmasi Sosial, Fakultas Farmasi, Universitas Indonesia \\ *Corresponding author: nisamaria@farmasi.ui.ac.id
}

\begin{abstract}
Background: Treatment guidelines of COVID-19 are changing continuously by involving many off-label and various symptomatic or supportive drugs. The use of these various drugs might increase the patient's risk of developing drug interactions.

Objective: The study aimed to analyze potential drug-drug interactions in COVID-19 inpatients and the correlated factors.

Method: A cross-sectional study was conducted in a hospital by using inpatients admitted from AugustDecember 2020. Potential drug-drug interaction was analyzed by using Lex-Interact ${ }^{\circledR}$ software.

Results: From 107 patients, the majority of them are in moderate severity-degree (98.1\%), having comorbidities $(93.5 \%)$, and polypharmacy $(98.1 \%)$. The average of potential drug interactions was $8.47 \pm$ 8,04, with most of the interaction in risk rating C-monitor therapy. Major potential drug interactions found were prolongation of QT interval and disturbance of drug absorption in the gastrointestinal tract. A positive correlation occurred between drug interactions found and comorbidity $(\mathrm{r}=0.436)$, number of drugs per prescription ( $\mathrm{r}=0.674)$, and length of stay $(\mathrm{r}=0.222)$

Conclusions: COVID-19 patient is at risk for developing potential drug interactions that can affect the patient's physiological condition and reduce drug effect. It is necessary to manage the medication schedule, therapy modification, administration route changing, dosage adjustment, and monitoring of effects that might occur because of the drug interactions.
\end{abstract}

Keywords: drug interaction, COVID-19, inpatient, correlated factor

\section{Intisari}

Latar belakang: Tatalaksana pengobatan COVID-19 terus berkembang dengan melibatkan berbagai jenis obat off-label dan berbagai obat terapi simptomatik ataupun suportif. Penggunaan berbagai jenis obat ini membuat pasien berisiko mengalami interaksi obat.

Tujuan: Penelitian ini bertujuan untuk menganalisis potensi interaksi antar obat yang dapat terjadi pada pasien COVID-19 rawat inap serta faktor yang mempengaruhinya.

Metode: Penelitian dilakukan dengan desain cross-sectional menggunakan sampel pasien rawat inap di rumah sakit pada periode Agustus-Desember 2020. Analisis potensi interaksi antar obat dilakukan dengan menggunakan Lexi-Interact $®$

Hasil: Sebanyak 107 sampel pasien didapatkan mayoritas dalam tingkat keparahan sedang (98,1\%), memiliki komorbid $(93,5 \%)$, dan polifarmasi $(98,1 \%)$. Rata-rata jumlah potensi interaksi obat yang dialami adalah $8,47 \pm 8,04$ dengan tingkat interaksi paling banyak pada kategori C (pantau terapi) $(54,61 \%)$. Potensi interaksi obat mayor yang banyak ditemukan adalah adanya perpanjangan pada interval QT serta gangguan absorpsi obat di saluran cerna. Terdapat korelasi positif antara potensi interaksi obat dengan faktor komorbid $(r=0,436)$, jumlah obat per resep $(r=0,674)$, serta lama rawat inap $(r=0,222)$.

Kesimpulan: Pasien COVID-19 memiliki risiko tinggi untuk mengalami potensi interaksi obat yang dapat mempengaruhi kondisi fisiologis pasien dan mengurangi efek terapi obat. Maka dari itu, perlu dilakukan pengaturan waktu minum, modifikasi terapi, perubahan rute pemberian, penyesuaian dosis, serta pemantauan efek obat yang mungkin muncul akibat interaksinya. 
182 | Kusumawardani, L.A. dkk /Jurnal Ilmiah Farmasi (Scientific Journal of Pharmacy) 17(2) AgustusDesember 2021, 182-197

Kata kunci : interaksi obat, COVID-19, rawat inap, faktor yang mempengaruhi

\section{Pendahuluan}

Pada awal Maret 2020, pemerintah Indonesia secara resmi mengumumkan kasus coronavirus disease 2019 (COVID-19) pertama di Indonesia. Total kasus per 26 Desember 2020 di Indonesia berjumlah 700.097 kasus terkonfirmasi COVID-19 dengan 20.847 kematian (Kemenkes, 2020). Sedangkan total kasus konfirmasi global COVID-19 mencapai 78.604.532 kasus dengan 1.744.235 kematian (WHO, 2020a). COVID-19 disebabkan oleh Severe Acute Respiratory Syndrome-related Coronavirus 2 (SARS-CoV-2). Virus ini mampu menyebar dengan cepat melalui kontak langsung dengan penderita, baik yang menunjukkan gejala maupun tidak (CDC, 2020).

Hingga saat ini, belum ada pengobatan spesifik untuk infeksi SARS-CoV-2 (Song et al., 2020). Dalam situasi seperti ini, pengobatan dilakukan dengan menggunakan obat off-label. Obat off-label adalah obat yang digunakan di luar indikasi obat yang tertera dalam label obat yang terdaftar. Obat ini dapat digunakan bila memiliki potensi manfaat (Shojaei \& Salari, 2020). Pada bulan Agustus 2020, lima organisasi profesi kedokteran di Indonesia, mengeluarkan buku Pedoman Tatalaksana COVID-19 Edisi 2. Dalam pedoman tersebut beberapa obat yang dapat dipertimbangkan untuk penanganan COVID-19 adalah klorokuin fosfat, hidroksiklorokuin, lopinavir/ritonavir, favipiravir, remdesivir, oseltamivir, azitromisin, levofloksasin, parasetamol, dan vitamin C (PDPI et al., 2020 ).

Penggunaan beberapa obat dalam penanganan pasien COVID-19 secara bersamaan dilaporkan adanya reaksi efek samping yang tidak diinginkan. Pada bulan Juli 2020, WHO melaporkan 155 kasus baru pada penggunaan hidroksiklorokuin dan 148 kasus diantaranya merupakan reaksi serius. Delapan kasus diantaranya berasal dari interaksi obat antara lopinavir/ritonavir dan directacting anticoagulants (DOACs) (WHO, 2020b). Studi yang dilakukan sebelumnya juga menunjukkan potensi interaksi obat pengobatan antivirus pada pasien COVID-19 dengan obat golongan antikoagulan, antiplatelet, dan fibrinolitik (Hodge et al., 2020).

Penelitian mengenai masalah terkait interaksi obat pada pasien COVID-19 perlu dilakukan mengingat belum adanya obat atau terapi spesifik dan beragamnya obat yang digunakan dalam penanganan kasus COVID-19. Data potensi interaksi obat pada pasien COVID-19 sangat diperlukan dalam pertimbangan pemilihan obat dan pemantauan terapi yang sesuai agar mampu mengoptimalkan hasil pengobatan dan mencegah reaksi obat yang tidak diinginkan. Penelitian ini bertujuan untuk menganalisis potensi interaksi obat yang terjadi pada pasien rawat inap COVID-19 di rumah sakit periode Agustus sampai Desember tahun 2020. 
183 | Kusumawardani, L.A. dkk /Jurnal Ilmiah Farmasi (Scientific Journal of Pharmacy) 17(2) AgustusDesember 2021, 182-197

\section{Metode}

\subsection{Desain penelitian}

Desain penelitian yang digunakan adalah desain penelitian cross-sectional, menggunakan data sekunder berupa rekam medis, resep, dan catatan pengobatan pasien COVID-19 rawat inap periode Agustus sampai Desember tahun 2020. Penelitian dilakukan di satu rumah sakit yang terletak di kawasan Depok, Jawa Barat. Protokol penelitian telah mendapatkan persetujuan izin pelaksanaan penelitian dan komite etik rumah sakit dengan Nomor: 007/SKPE/KKO/2021/00.

Alat yang digunakan dalam penelitian ini adalah Lexi-Interact@ (Lexicomp Drug Interaction) yang dikeluarkan oleh Wolters Kluwer untuk menganalisis potensi interaksi obat yang terjadi berdasarkan tingkat risikonya. Kategori interaksi obat yang dikelompokkan berdasarkan kategori A, B, C, D, atau X. Kategori A menunjukkan tidak adanya bukti terkait interaksi obat; kategori B menunjukkan adanya bukti potensi interaksi obat namun efek secara klinisnya sedikit; kategori C menunjukkan adanya signifikansi secara klinis sehingga diperlukan pemantauan; kategori D menunjukkan dibutuhkan perubahan dosis, alternatif terapi, ataupun monitoring; kategori $\mathrm{X}$ menunjukkan sebaiknya dihindari karena risikonya lebih besar (Shetty et al., 2018).

\subsection{Sampel penelitian}

Kriteria inklusi sampel pada penelitian ini adalah: pasien rawat inap yang didiagnosa positif COVID-19 pada bulan Agustus hingga Desember 2020; pasien dengan tingkat keparahan COVID-19 sedang hingga berat; pasien berusia lebih dari 17 tahun; pasien mengonsumsi 2 obat atau lebih yang salah satunya merupakan obat golongan antivirus atau antibiotik yang direkomendasikan berdasarkan Pedoman Tatalaksana COVID-19 Edisi 2. Rekam medis pasien yang pernah mendapatkan perawatan ICU dan rekam medis yang tidak lengkap akan dikeluarkan dari penelitian ini. Pengambilan sampel dilakukan dengan menggunakan metode consecutive sampling.

\subsection{Analisis data}

Analisis data dilakukan dengan uji statistik menggunakan IBM SPSS Statistics Premium versi 24 yang terdiri dari analisis univariat dan bivariat. Analisis univariat digunakan untuk melihat distribusi gambaran karakteristik pasien, peresepan obat, serta interaksi obat. Selanjutnya, dilakukan analisis bivariat untuk menganalisis faktor korelasi komorbid, jumlah obat per resep, dan lama rawat inap terhadap potensi interaksi obat dengan uji korelasi Spearman's rho. Hasil analisis dinyatakan signifikan bila nilai $\mathrm{p}<0,05$. 
184 | Kusumawardani, L.A. dkk /Jurnal Ilmiah Farmasi (Scientific Journal of Pharmacy) 17(2) AgustusDesember 2021, 182-197

\section{Hasil dan pembahasan}

Total sebanyak 107 rekam medis yang memenuhi kriteria inklusi dan eksklusi menjadi sampel dalam penelitian dan dianalisis. Gambaran karakteristik sampel penelitian dapat pada Tabel 1.

Tabel 1. Demografi dan karakteristik klinis sampel penelitian

\begin{tabular}{lcc}
\hline \multicolumn{1}{c}{ Studi Populasi } & Frekuensi (n=107) & Persentase (\%) \\
\hline Jenis kelamin & 57 & \\
$\quad$ Laki-laki & 50 & 53,3 \\
$\quad$ Perempuan & & 46,7 \\
Usia & 8 & \\
$\quad$ Remaja akhir (18 - 25 tahun) & 46 & 7,5 \\
$\quad$ Dewasa (26 - 45 tahun) & 47 & 43,0 \\
$\quad$ Lansia (46 - 65 tahun) & 6 & 43,9 \\
$\quad$ Manula (di atas 65 tahun) & & 5,6 \\
BMI & 1 & \\
$\quad$ Underweight (di bawah 18,5) & 33 & 0,9 \\
$\quad$ Normal (18,5 - 24,9) & 52 & 30,8 \\
$\quad$ Pre-obesitas (25,0 - 29,9) & 21 & 48,6 \\
Obesitas (di atas 30,0) & & 19,65 \\
Tingkat keparahan COVID-19 & 105 & 98,1 \\
$\quad$ Sedang & 2 & 1,9 \\
Berat & & \\
Komorbid & 7 & 6,5 \\
Tanpa komorbid & 100 & 93,5 \\
Dengan komorbid & 34 & 34,0 \\
$\quad$ Hipertensi & 21 & 21,0 \\
$\quad$ Obesitas & 16 & 16,0 \\
$\quad$ Diabetes & & 97,2 \\
Lama rawat inap & 104 & 2,8 \\
$\quad$ 6 hari & 3 &
\end{tabular}

Data pasien COVID-19 yang diperoleh di rumah sakit periode Agustus hingga Desember 2020 menunjukkan jumlah pasien laki-laki (53,3\%) lebih banyak dibandingkan pasien perempuan $(46,7 \%)$. Studi sebelumnya menunjukkan prevalensi terjadinya COVID-19 dominan pada laki-laki. Salah satu fenomena yang mendasari hal ini adalah tingginya konsentrasi ACE2 (Angiotensin Converting Enzyme 2) di testis. Selain itu, kebiasaan merokok yang lebih banyak dilakukan laki-laki juga dapat meningkatkan konsentrasi ACE2 di paru-paru sehingga memungkinkan virus untuk masuk ke dalam sel (Mukherjee \& Pahan, 2021).

Rata-rata usia pasien pada penelitian adalah 44,5 \pm 13,8 dengan kelompok lansia (46- 65 tahun) adalah yang terbanyak (43,9\%). Kelompok usia ini rentan terhadap berbagai penyakit 
185 | Kusumawardani, L.A. dkk /Jurnal Ilmiah Farmasi (Scientific Journal of Pharmacy) 17(2) AgustusDesember 2021, 182-197

karena fungsi fisiologisnya mulai menurun, termasuk sistem imun tubuh yang diperankan oleh sel B dan sel T. Selain itu, produksi sitokin proinflamasi yang berlebih juga menyebabkan defisiensi dalam mengendalikan replikasi virus dan respon proinflamasi yang berkepanjangan. Faktor risiko lain yang dimiliki oleh pasien lanjut usia adalah komorbid (Parohan et al., 2020).

Sebanyak 52 pasien COVID-19 (48,6\%) pada penelitian ini memiliki nilai BMI di rentang $25,0-29,9 \mathrm{~kg} / \mathrm{m}^{2}$ yang termasuk dalam kategori pre-obesitas. Studi yang dilakukan sebelumnya menjelaskan pasien dengan BMI lebih dari $25 \mathrm{~kg} / \mathrm{m}^{2}$ mengalami penurunan sistem imun yang membuat kelompok pasien ini rentan terhadap infeksi. Selain itu, ekspresi reseptor ACE2 pada seseorang yang mengalami obesitas akan semakin meningkat karena jumlah jaringan adiposa atau lemak yang lebih banyak dibanding seseorang non-obesitas (Hussain et al., 2020).

Sampel penelitian ini sebagian besar adalah kasus dengan derajat sedang $(98,1 \%)$. Pasien COVID-19 derajat berat lebih banyak membutuhkan perawatan tambahan, sehingga pasien ini akan lebih banyak ditemukan di perawatan ICU yang dalam penelitian ini dieksklusikan (PDPI et al., 2020 ). Pasien COVID-19 ini sebagian besar (97,2\%) dirawat selama $\geq 6$ hari di rumah sakit.

Berdasarkan data sampel yang diperoleh, 100 pasien (93,5\%) memiliki setidaknya 1 komorbid. Hipertensi $(34,0 \%)$ adalah komorbid terbanyak yang diderita oleh pasien, diikuti oleh obesitas $(21,0 \%)$ dan diabetes (16,0\%). Studi yang dilakukan Kulkarni et al., menyatakan kondisi hipertensi mengakibatkan sejumlah perubahan patofisiologis dari sistem kardiovaskular, seperti hipertrofi ventrikel kiri dan fibrosis. Kondisi ini menyebabkan pasien hipertensi sangat rentan terhadap SARS-CoV-2 (Kulkarni et al., 2020). Sedangkan pasien obesitas akan mengalami penurunan sistem imun dan jumlah jaringan adiposa yang lebih banyak dibanding pasien tanpa obesitas. Hal ini membuat pasien obesitas lebih rentan terhadap infeksi (Hussain et al., 2020). Pasien diabetes cenderung terpapar dengan infeksi karena kemampuan sel fagosit yang terganggu dan adanya peningkatan jumlah reseptor ACE2 (Ejaz et al., 2020).

Pasien COVID-19 dengan komorbid memiliki angka morbiditas dan kematian yang lebih tinggi dibanding pasien tanpa komorbid. Paparan SARS-CoV-2 pada pasien komorbid dapat merugikan organ-organ lainnya, seperti paru-paru, jantung, ginjal, dan hati. Komplikasi dapat berakhir dengan kondisi yang tidak diinginkan karena pasien mengalami kegagalan organ ganda, syok, sindrom gangguan pernapasan akut, gagal jantung, aritmia, gagal ginjal, hingga kematian (Ejaz et al., 2020). Selain itu, adanya komorbid juga mengakibatkan polifarmasi dan peningkatan risiko interaksi obat pada pasien COVID-19 (Rahman et al., 2020). Oleh karena itu, manajemen yang efisien harus diberikan kepada pasien dengan komorbid agar memberikan perawatan yang optimal dan mengurangi angka kematian (Ejaz et al., 2020). 
186 | Kusumawardani, L.A. dkk /Jurnal Ilmiah Farmasi (Scientific Journal of Pharmacy) 17(2) AgustusDesember 2021, 182-197

\subsection{Gambaran peresepan obat pada pasien COVID-19}

Peneliti menghitung gambaran peresepan yang diberikan kepada pasien COVID-19 berdasarkan golongan obat antibiotik dan antivirus yang sesuai dengan Pedoman Tatalaksana COVID-19 Edisi 2 yang dapat dilihat pada Tabel 2.

Tabel 2. Gambaran profil pengobatan antibiotik dan antivirus utama sesuai Pedoman Tatalaksana COVID-19 Edisi 2

\begin{tabular}{lcc}
\hline \multicolumn{1}{c}{ Golongan Obat } & Frekuensi (n=107) & Persentase (\%) \\
\hline Antibiotik & 66 & 61,68 \\
$\quad$ Azitromisin & 38 & 35,51 \\
$\quad$ Levofloksasin & & \\
Antivirus & 68 & 63,55 \\
Oseltamivir & 37 & 34,58 \\
Klorokuin & 16 & 14,95 \\
Favipiravir & 4 & 3,74 \\
Hidroksiklorokuin & 1 & 0,93 \\
Remdesivir & 0 & 0 \\
Lopinavir/ritonavir & & \\
\hline
\end{tabular}

Oseltamivir (63,55\%) menjadi antivirus yang paling banyak diberikan kepada pasien COVID-19 di rentang Agustus hingga Desember 2020. Sedangkan azitromisin (61,68\%) menjadi antibiotik yang paling tinggi penggunaannya di rentang tersebut. Pasien juga diberikan terapi simptomatik, terapi untuk komorbid, vitamin dan suplemen, serta obat untuk indikasi lainnya seperti tercantum dalam Gambar 1.

Vitamin dan suplemen banyak digunakan pada pasien COVID-19 untuk menjaga sistem imun pasien. Pemberian agen gastrointestinal yang tinggi digunakan sebagai terapi simptomatik seperti mual, muntah, dan gangguan lambung. Agen respirasi yang banyak diberikan adalah Nasetilsistein (84,11\%) yang berfungsi sebagai mukolitik. Agen kardiovaskular diberikan untuk penanganan komorbid pasien, terutama hipertensi yang merupakan komorbid terbanyak dalam penelitian ini. Selain itu, beberapa pasien juga menggunakan parasetamol, yang merupakan analgesik dan antipiretik yang bekerja pada sistem syaraf untuk mengatasi gejala demam, sakit kepala, ataupun nyeri. Penggunaan obat koagulasi diindikasikan untuk pasien yang mengalami komplikasi pendarahan maupun trombosis. Antiinfeksi lainnya, baik antibiotik maupun antivirus, digunakan untuk mengatasi infeksi penyerta lain yang terjadi akibat bakteri atau virus. Bila diperlukan, kortikosteroid dapat diberikan untuk meredakan peradangan atau inflamasi. 
187 | Kusumawardani, L.A. dkk /Jurnal Ilmiah Farmasi (Scientific Journal of Pharmacy) 17(2) AgustusDesember 2021, 182-197

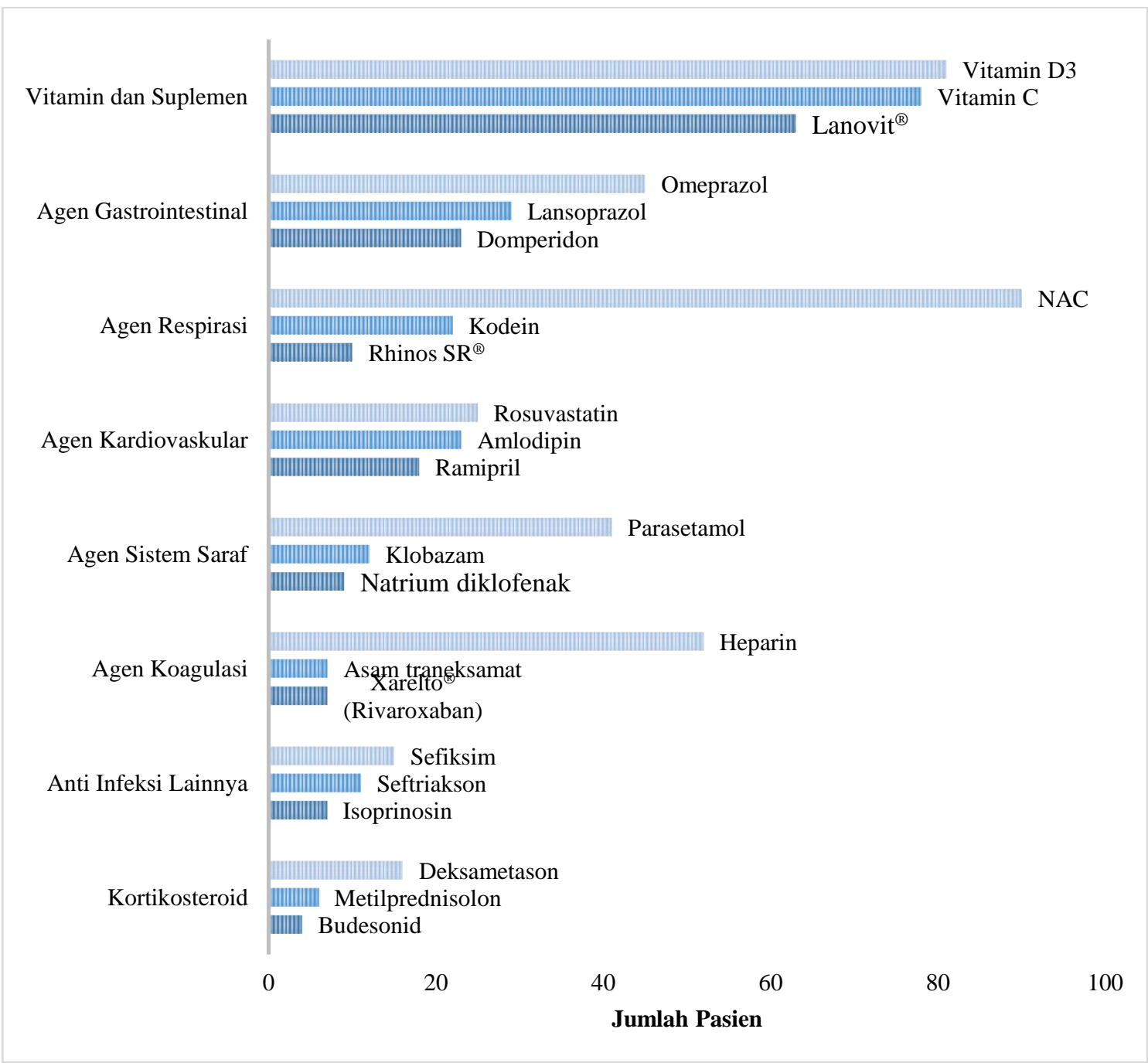

Gambar 1. Gambaran 3 besar profil pengobatan lain berdasarkan kelas farmakologi pada pasien COVID-19

Selain itu, peneliti juga menghitung jumlah obat yang diberikan pada setiap resep yang diterima oleh sampel penelitian. Dari 107 pasien, diperoleh 322 resep. Pembagian kelompok jumlah obat dalam resep ini berdasarkan data yang diperoleh. Jumlah obat dalam resep yang paling sedikit adalah 4 macam obat dan yang paling banyak adalah 20 macam obat yang kemudian dibagi dalam tiga interval yaitu 4-8 obat (33,9\%), 9-14 obat (59\%), dan $15-20$ obat $(7,1 \%)$. Berdasarkan data yang diperoleh, jumlah resep yang tidak termasuk polifarmasi hanya berjumlah 6 resep $(1,9 \%)$ dan jumlah resep yang termasuk polifarmasi (jumlah obat $\geq 5$ ) berjumlah 316 resep $(98,1 \%)$. 
188 | Kusumawardani, L.A. dkk /Jurnal Ilmiah Farmasi (Scientific Journal of Pharmacy) 17(2) AgustusDesember 2021, 182-197

Tabel 3. Gambaran jumlah obat dalam resep

\begin{tabular}{lcc}
\hline \multicolumn{1}{c}{ Jumlah Obat dalam Resep } & Frekuensi (n=322) & Persentase (\%) \\
\hline $4-8$ & 109 & 33,9 \\
$9-14$ & 190 & 59,0 \\
$15-20$ & 23 & 7,1 \\
\hline
\end{tabular}

Beberapa pendapat menyatakan bahwa polifarmasi harus ditentukan berdasarkan kesesuaian klinis. Meskipun demikian, polifarmasi sering didefinisikan sebagai penggunaan 5 macam obat atau lebih secara bersamaan (Iloanusi et al., 2021). Risiko terjadinya kejadian yang tidak diharapkan meningkat seiring dengan peningkatan jumlah obat yang digunakan. Polifarmasi dapat menyebabkan berbagai kemungkinan interaksi obat, komplikasi terkait obat, ketidakpatuhan, kualitas hidup yang lebih rendah, hingga peningkatan risiko kematian (Rahman et al., 2020). Studi yang dilakukan oleh Iloanusi et al. menunjukkan pasien yang mengonsumsi jumlah obat lebih banyak (rata-rata 9 obat) memiliki risiko 4 kali lebih besar untuk mengalami reaksi obat yang tidak dikehendaki dibandingkan pasien yang dengan jumlah obat lebih sedikit (rata-rata 5 obat) (Iloanusi et al., 2021).

\subsection{Analisis potensi interaksi obat pada pasien COVID-19}

Pada Tabel 4 terlihat jumlah potensi interaksi obat yang terjadi pada pasien COVID-19 pada penelitian ini. Rata-rata jumlah potensi interaksi obat yang dialami oleh pasien COVID-19 adalah $8,47 \pm 8,04$ dengan sebagian besar pasien mengalami lebih dari 5 potensi interaksi obat $(54,2 \%)$.

Tabel 4. Jumlah potensi interaksi obat pada pasien COVID-19

\begin{tabular}{cc}
\hline Jumlah Potensi Interaksi Obat & Jumlah Pasien, $\mathbf{n = 1 0 7}(\mathbf{\%})$ \\
\hline 0 & $4(3,7)$ \\
$1-2$ & $13(12,1)$ \\
$3-5$ & $32(29,9)$ \\
$>5$ & $58(54,2)$ \\
\hline
\end{tabular}

Berdasarkan data yang telah dianalisis, potensi interaksi obat yang terjadi pada pasien COVID19 di rumah sakit berjumlah 304 kasus potensi interaksi obat seperti terlihat dalam Gambar 2. 
189 | Kusumawardani, L.A. dkk /Jurnal Ilmiah Farmasi (Scientific Journal of Pharmacy) 17(2) AgustusDesember 2021, 182-197

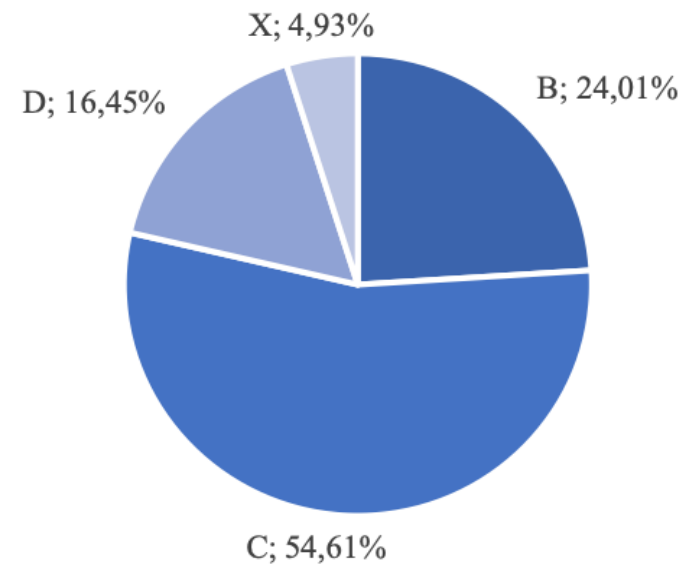

Gambar 2. Distribusi potensi interaksi obat pada pasien COVID-19 berdasarkan kategori secara keseluruhan $(n=304)$

Potensi interaksi obat yang ditemukan adalah kategori B, C, D, dan X secara berturut-turut sebanyak 24,01\%; 54,61\%; 16,45\%, dan 4,93\%.

\subsection{Interaksi obat yang melibatkan antibiotik dan antivirus}

Dari 304 potensi interaksi obat yang ditemukan, 67 di antaranya adalah interaksi obat yang melibatkan antibiotik dan antivirus seperti terlihat pada Gambar 3.

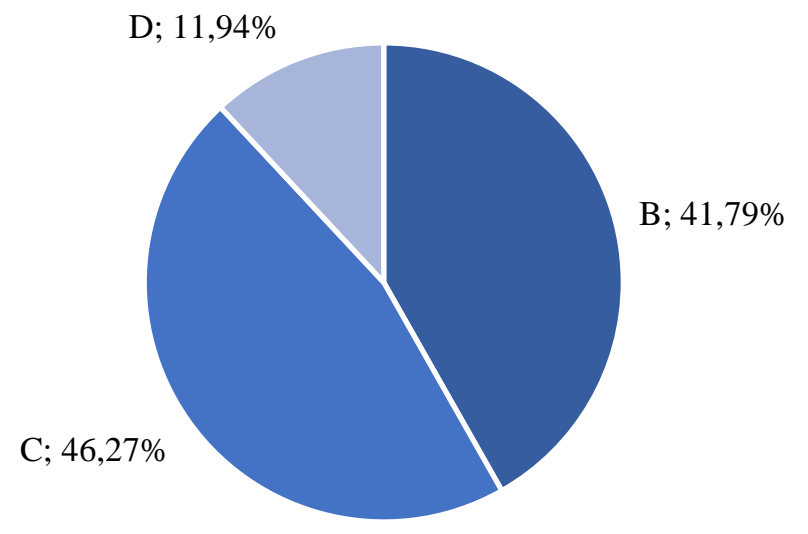

Gambar 3. Distribusi potensi interaksi obat pada pasien COVID-19 berdasarkan kategori yang melibatkan antibiotik dan antivirus $(n=67)$

Potensi interaksi kategori B yang terbanyak ditemukan adalah interaksi antara klorokuin dan parasetamol (asetaminofen) dengan frekuensi sebanyak 12. Klorokuin dapat meningkatkan konsentrasi serum dari asetaminofen dan sebaliknya, asetaminofen dapat meningkatkan 
190 | Kusumawardani, L.A. dkk /Jurnal Ilmiah Farmasi (Scientific Journal of Pharmacy) 17(2) AgustusDesember 2021, 182-197

konsentrasi serum dari klorokuin (Rezaee et al., 2021). Pada interaksi ini tidak perlu dilakukan tindakan apapun karena bukti klinik hanya sedikit.

Interaksi terbanyak pada kategori $\mathrm{C}$ adalah interaksi antara azitromisin dan klorokuin, yaitu sebanyak 18. Penggunaan azitromisin dan klorokuin bersamaan dapat mengakibatkan perpanjangan interval QT yang dapat menyebabkan aritmia jantung sehingga perlu memantau interval QT pasien (Mercuro et al., 2020). Potensi interaksi obat kategori D dapat dilihat pada Tabel 5.

Tabel 5. Potensi interaksi obat kategori D pada antibiotik dan antivirus

\begin{tabular}{lccc}
\hline \multicolumn{1}{c}{ Kombinasi Obat } & $\begin{array}{c}\text { Frekuensi, } \\
\mathbf{n = 1 0 7} \\
\mathbf{( \% )}\end{array}$ & Mekanisme & Potensi Interaksi \\
\hline Azitromisin + Domperidon & $14(13,08)$ & Farmakodinamik & Perpanjangan interval QT \\
Klorokuin + Domperidon & $9(8,41)$ & Farmakodinamik & Perpanjangan interval QT \\
Levofloksasin + Zink sulfat & $9(8,41)$ & Farmakokinetik & Gangguan absorpsi antibiotik \\
Levofloksasin + Domperidon & $7(6,54)$ & Farmakodinamik & Perpanjangan interval QT \\
Levofloksasin + Fero fumarat & $7(6,54)$ & Farmakokinetik & Gangguan absorpsi antibiotik \\
Levofloksasin + Magnesium karbonat & $7(6,54)$ & Farmakokinetik & Gangguan absorpsi antibiotik \\
Klorokuin + Antasida & $3(2,80)$ & Farmakokinetik & Gangguan absorpsi antibiotik \\
Levofloksasin + Sukralfat & $2(1,87)$ & Farmakokinetik & Gangguan absorpsi antibiotik \\
\hline
\end{tabular}

Interaksi obat kategori D dengan yang paling banyak ditemukan adalah perpanjangan interval QT. Interval QT adalah waktu yang dibutuhkan jantung untuk melakukan repolarisasi setelah proses depolarisasi. Klorokuin (Isbister \& Page, 2013), levofloksasin, azitromisin (Schwartz \& Woosley, 2016), dan domperidon (Buffery \& Strother, 2015) termasuk ke dalam obat yang dapat memperpanjang interval QT. Pada hasil penelitian yang tercantum dalam Tabel 5, kombinasi obat tersebut banyak digunakan. Penggunaan kombinasi obat ini berpotensi menyebabkan interaksi farmakodinamik melalui perpanjangan interval QT. Perpanjangan interval QT dapat meningkatkan risiko aritmia, bahkan risiko toksisitas yang lebih serius. Namun, bukti mengenai risiko dengan kombinasi ini masih terbatas. Untuk menghindari risiko interaksi obat ini, disarankan untuk mempertimbangkan alternatif dari kombinasi ini. Jika tidak memungkinkan, lakukan pemantauan interval QT dan aritmia. Ada beberapa faktor risiko yang perlu diperhatikan karena memiliki efek toksisitas yang cenderung berisiko lebih besar, diantaranya adalah usia yang lebih tua, perempuan, bradikardia, penyakit jantung, dan konsentrasi obat yang tinggi (Meid et al., 2017).

Pemberian levofloksasin bersama sukralfat dan suplemen yang mengandung seng (Zn), magnesium (Mg), dan besi (Fe) dapat mengurangi absorpsi dari levofloksasin melalui pembentukan 
191 | Kusumawardani, L.A. dkk /Jurnal Ilmiah Farmasi (Scientific Journal of Pharmacy) 17(2) AgustusDesember 2021, 182-197

kompleks (chelat) yang tidak dapat diserap di saluran pencernaan. Interaksi obat-obat ini terbatas pada rute pemberian oral. Tindakan yang dapat dilakukan agar interaksi ini tidak terjadi adalah dengan memberikan levofloksasin setidaknya 2 jam sebelum atau setelah pemberian obat-obat yang mengandung kation tersebut (Pitman et al., 2019).

Klorokuin adalah senyawa basa lemah yang terakumulasi dalam lingkungan yang asam untuk aktivitas terapi beberapa patogen seperti Plasmodium falciparum. Obat-obat yang mempengaruhi $\mathrm{pH}$, seperti golongan antasida, berpotensi menyebabkan interaksi farmakokinetik melalui penurunan absorpsi dari klorokuin. Tindakan yang dapat dilakukan untuk menghindari interaksi ini adalah dengan memberikan interval pada dosis klorokuin dan antasida setidaknya 4 jam apabila tidak dapat dilakukan modifikasi terapi (Doyno et al., 2021).

\subsection{Interaksi obat yang melibatkan terapi simptomatik, suportif, dan pengobatan komorbid}

Selain antibiotik dan antivirus, terapi simptomatik, suportif, dan pengobatan komorbid juga berpotensi adanya interaksi obat. Hal ini perlu diperhatikan terutama pada kategori D dan X. Pada Tabel 6 berikut ini adalah potensi interaksi kategori D dan X yang ditemukan dengan frekuensi kejadian lebih atau sama dengan 5.

Tabel 6. Potensi interaksi obat kategori D dan X pada terapi simptomatik, suportif, dan pengobatan komorbid dengan prevalensi tinggi

\begin{tabular}{lcccc}
\hline \multicolumn{1}{c}{ Kombinasi Obat } & $\begin{array}{c}\text { Kategori } \\
\text { Interaksi }\end{array}$ & $\begin{array}{c}\text { Frekuensi, } \\
\mathbf{n = 1 0 7}(\%)\end{array}$ & Mekanisme & Potensi Interaksi \\
\hline Sukralfat + Vitamin D3 (X) & $\mathrm{X}$ & $14(13,08)$ & Farmakokinetika & Gangguan absorpsi \\
Deksametason+ $\mathrm{MgCO}_{3}$ (D) & $\mathrm{D}$ & $8(7,84)$ & Farmakodinamika & $\downarrow$ Bioavaibilitas Obat \\
Setirizin + $\mathrm{KCl}(\mathrm{X})$ & $\mathrm{X}$ & $7(6,54)$ & Farmakodinamika & Ulserasi GI \\
$\mathrm{KCl}+$ Spironolakton (D) & $\mathrm{D}$ & $7(6,54)$ & Farmakodinamika & Hiperkalemia \\
Loratadin/Pseudoefedrin+ & $\mathrm{X}$ & $6(5,61)$ & Farmakokinetika & Ulserasi GI \\
$\mathrm{KCl}(\mathrm{X})$ & & & & \\
\hline
\end{tabular}

Ket: MgCO3 (Magnesium Karbonat); KCl (Kalium Klorida); GI (Gastrointestinal); $\downarrow$ (penurunan)

\subsubsection{Sukralfat dengan vitamin D3}

Penggunaan vitamin D3 dengan produk yang mengandung aluminium bersamaan dapat meningkatkan absorpsi aluminium sehingga menyebabkan peningkatan konsentrasi serum hingga toksisitas aluminium. Oleh karena itu, penggunaan vitamin D3 harus dihindari dari produk yang mengandung aluminium, seperti sukralfat (Moon et al., 1992). 
192 | Kusumawardani, L.A. dkk /Jurnal Ilmiah Farmasi (Scientific Journal of Pharmacy) 17(2) AgustusDesember 2021, 182-197

\subsubsection{Deksametason dengan magnesium karbonat}

Penggunaan obat yang mengandung magnesium dengan golongan kortikosteroid dapat menurunkan bioavailabilitas dari golongan kortikosteroid. Studi yang dilakukan sebelumnya melaporkan penurunan bioavailabilitas deksametason sebanyak 75\% ketika diberikan bersamaan dengan garam magnesium. Penggunaan deksametason dengan magnesium karbonat harus dihindari (Naggar et al., 1978).

\subsubsection{Cetirizin dan loratadin/pseudoefedrin dengan kalium klorida}

Cetirizin dan loratadine/pseudoefedrin memiliki efek antikolinergik. Penelitian terdahulu menunjukkan bahwa pasien yang mendapatkan terapi kalium klorida dengan antikolinergik memiliki risiko 2,5 kali lebih besar untuk mengalami pendarahan gastrointestinal di bagian atas. Salah satu efek dari penggunaan antikolinergik adalah menurunnya motilitas gastrointestinal. Sediaan kalium klorida harus dihindari pada pasien yang mengonsumsi antikolinergik karena berisiko mengalami iritasi lambung, usus, dan ulserasi akibat lamanya kontak sediaan kalium klorida dengan mukosa gastrointestinal (Gueta et al., 2021). Apabila kombinasi ini akan digunakan sebaiknya monitor gejala yang muncul pada saluran pencernaan.

\subsubsection{Kalium klorida dengan spironolakton}

Kalium klorida dan spironolakton adalah obat yang dapat menyebabkan hiperkalemia. Penggunaan kedua obat ini secara bersamaan dapat meningkatkan efek hiperkalemia pada pasien (Perazella, 2000). Penelitian sebelumnya menunjukkan kejadian hiperkalemia meningkat hingga tiga kali pada pasien yang menggunakan spironolakton dengan kalium klorida dibandingkan pasien yang hanya menerima spironolakton saja. Oleh karena itu, pemberian kalium klorida dengan spironolakton harus dihindari (Winter, 1973).

\subsection{Faktor yang berhubungan dengan interaksi obat}

Hubungan antara komorbid, jumlah obat per resep, dan lama rawat inap terhadap potensi interaksi obat dianalisis menggunakan uji Spearman's rho seperti terlihat pada Tabel 7. Koefisien korelasi antara komorbid serta jumlah obat resep terhadap potensi interaksi obat menunjukkan hasil positif dengan tingkat korelasi sedang $(p<0,05)$. Hal ini menunjukkan bahwa semakin banyak jumlah komorbid yang diderita pasien atau semakin banyak jumlah obat yang diterima pasien, maka semakin besar potensi interaksi obat yang terjadi. Kesimpulan ini sejalan dengan penelitian lain yaitu peningkatan jumlah obat dan komorbiditas yang digunakan oleh pasien berhubungan dengan kejadian interaksi obat (Shetty et al., 2018). 
193 | Kusumawardani, L.A. dkk /Jurnal Ilmiah Farmasi (Scientific Journal of Pharmacy) 17(2) AgustusDesember 2021, 182-197

Tabel 7. Korelasi antara komorbid, jumlah obat, dan lama rawat inap terhadap potensi interaksi obat

\begin{tabular}{lcccc}
\hline \multicolumn{2}{c}{ Faktor yang Mempengaruhi } & \multicolumn{2}{c}{ Interaksi Obat } & \multicolumn{2}{c}{ Analisis Korelasi } \\
\hline \multicolumn{1}{c}{ Jenis } & Rata-rata \pm SD & Rata-rata \pm SD & r & P \\
\hline Komorbid & $2,93 \pm 1,83$ & $5,00 \pm 6,17$ & 0,304 & $<0,001^{*}$ \\
Jumlah Obat per Resep & $9,91 \pm 2,98$ & $6,74 \pm 6,17$ & 0,674 & $<0,001^{*}$ \\
Lama Rawat Inap & $12,00 \pm 4,14$ & $6,00 \pm 8,05$ & 0,222 & $0,022^{*}$ \\
\hline
\end{tabular}

Keterangan: $\mathrm{r}=$ Nilai korelasi berdasarkan uji korelasi Spearman's rho; $\mathrm{p}=$ Nilai signifikansi; $\mathrm{SD}=$ Standar deviasi;

$*=$ Terdapat hubungan yang signifikan $(\mathrm{p}<0,05)$ antara variabel faktor dengan potensi interaksi obat

Koefisien korelasi antara lama rawat inap dengan potensi interaksi obat menunjukkan hasil positif dengan tingkat korelasi lemah $(\mathrm{p}<0,05)$. Hal ini menunjukkan bahwa semakin lama pasien dirawat inap di rumah sakit, maka semakin besar potensi interaksi obat yang terjadi. Hasil analisis ini sejalan dengan penelitian lain dimana interaksi obat mayor yang terjadi mungkin saja berkontribusi dalam peningkatan waktu rawat inap (Lima et al., 2020). Hal ini dapat menunjukkan bahwa pasien dengan durasi rawat inap lebih lama memiliki risiko potensi interaksi obat yang lebih tinggi karena memungkinkan pasien menerima lebih banyak obat dibandingkan pasien dengan durasi rawat inap lebih cepat (Moura et al., 2009).

\subsection{Keterbatasan penelitian}

Hasil penelitian ini dapat dijadikan dasar untuk penelitian lebih lanjut dan pertimbangan dalam memberikan terapi pada pasien COVID-19. Penelitian ini memiliki beberapa keterbatasan, diantaranya interaksi obat yang ditemukan hanya diketahui secara teoritis sehingga tidak diketahui apakah interaksi obat tersebut terjadi secara klinis atau tidak dan tidak diketahui apa yang dilakukan oleh tenaga kesehatan. Data pada rekam medis juga tidak menjelaskan kondisi pasien setelah minum obat. Selain itu, penelitian ini hanya melakukan analisis interaksi obat dengan obat sehingga tidak melihat interaksi antara obat dengan makanan atau minuman. Penelitian selanjutnya dapat menganalisis interaksi obat yang terjadi secara klinis dan interaksi obat dengan makanan atau minuman.

\section{Kesimpulan}

Potensi interaksi obat yang ditemukan pada pasien COVID-19 dengan derajat sedang-berat yang menerima terapi antibiotik, antivirus, simptomatik dan terapi untuk penanganan komorbid dalam penelitian ini berada pada kategori B (24,01\%), C (54,61\%), D (16,45\%), dan X (4,93\%). Potensi interaksi obat kategori D yang banyak terjadi adalah azitromisin dengan domperidon (perpanjangan interval QT), klorokuin dengan domperidon (perpanjangan interval QT), dan levofloksasin dengan zink sulfat (mengurangi absorpsi levofloksasin). Potensi interaksi obat kategori X yang banyak terjadi adalah sukralfat dengan vitamin D3 (meningkatkan absorpsi 
194 | Kusumawardani, L.A. dkk /Jurnal Ilmiah Farmasi (Scientific Journal of Pharmacy) 17(2) Agustus-

Desember 2021, 182-197

aluminium). Potensi Interaksi kategori $\mathrm{D}$ dan $\mathrm{X}$ ini memerlukan perhatian khusus, dimana rekomendasi yang dapat dilakukan untuk potensi interaksi ini adalah mengatur jadwal pemberian obat, mempertimbangkan penggunaan kombinasi obat lain, tetapi jika tidak memungkinkan, dapat lakukan pemantauan potensi terjadinya interaksi obat oleh tenaga kesehatan. Peningkatan jumlah obat yang diterima oleh pasien, lama perawatan dirumah sakit, dan adanya komorbid dapat berkorelasi positif dengan terjadinya potensi interaksi obat $(\mathrm{p}<0,05)$.

\section{Ucapan terimakasih}

Peneliti mengucapkan terima kasih kepada semua tim di rumah sakit yang telah membantu dalam pengumpulan data untuk penelitian ini serta Universitas Indonesia yang telah membantu pendanaan penelitian sebagai hibah IRP-A.

\section{Daftar pustaka}

Buffery, P. J., \& Strother, R. M. (2015). Domperidone safety: a mini-review of the science of QT prolongation and clinical implications of recent global regulatory recommendations. $N Z$ Med J, 128(1416), 66-74.

CDC. (2020). How COVID-19 Spreads. Retrieved fromhttps://www.cdc.gov/coronavirus/2019ncov/prevent-getting-sick/how-covidspreads.html?CDC AA refVal=https\%3A\%2F\%2Fwww.cdc.gov\%2Fcoronavirus\%2F2019ncov\%2Fprepare\%2Ftransmission.html

Doyno, C., Sobieraj, D. M., \& Baker, W. L. (2021). Toxicity of chloroquine and hydroxychloroquine following therapeutic use or overdose. Clin Toxicol (Phila), 59(1), 12-23. doi:10.1080/15563650.2020.1817479

Ejaz, H., Alsrhani, A., Zafar, A., Javed, H., Junaid, K., Abdalla, A. E., Abosalif, K. O. A., Ahmed, Z., \& Younas, S. (2020). COVID-19 and comorbidities: Deleterious impact on infected patients. $J$ Infect Public Health, 13(12), 1833-1839. doi:10.1016/j.jiph.2020.07.014

Gueta, I., Markovits, N., Halkin, H., \& Loebstein, R. (2021). Concomitant oral potassium chloride and anticholinergic therapy is associated with upper gastrointestinal bleeding: A cohort study. Br J Clin Pharmacol, 87(4), 2064-2069. doi:10.1111/bcp.14616

Hodge, C., Marra, F., Marzolini, C., Boyle, A., Gibbons, S., Siccardi, M., Burger, D., Back, D., \& Khoo, S. (2020). Drug interactions: a review of the unseen danger of experimental COVID-19 therapies. J Antimicrob Chemother, 75(12), 3417-3424. doi:10.1093/jac/dkaa340

Hussain, A., Mahawar, K., Xia, Z., Yang, W., \& El-Hasani, S. (2020). Obesity and mortality of COVID19. Meta-analysis. Obes Res Clin Pract, 14(4), 295-300. doi:10.1016/j.orcp.2020.07.002

Iloanusi, S., Mgbere, O., \& Essien, E. J. (2021). Polypharmacy among COVID-19 patients: A systematic review. J Am Pharm Assoc (2003), 61(5), e14-e25. doi:10.1016/j.japh.2021.05.006

Isbister, G. K., \& Page, C. B. (2013). Drug induced QT prolongation: the measurement and assessment of the QT interval in clinical practice. Br J Clin Pharmacol, 76(1), 48-57. doi:10.1111/bcp.12040

Kemenkes. (2020). Situasi Virus COVID-19 di Indonesia. Retrieved from https://covid19.go.id

Kulkarni, S., Jenner, B. L., \& Wilkinson, I. (2020). COVID-19 and hypertension. J Renin Angiotensin Aldosterone Syst, 21(2), 1470320320927851. doi:10.1177/1470320320927851 
195 | Kusumawardani, L.A. dkk /Jurnal Ilmiah Farmasi (Scientific Journal of Pharmacy) 17(2) Agustus-

Desember 2021, 182-197

Lima, E. D. C., Camarinha, B. D., Ferreira Bezerra, N. C., Panisset, A. G., Belmino de Souza, R., Silva, M. T., \& Lopes, L. C. (2020). Severe Potential Drug-Drug Interactions and the Increased Length of Stay of Children in Intensive Care Unit. Front Pharmacol, 11, 555407. doi:10.3389/fphar.2020.555407

Meid, A. D., Bighelli, I., Mächler, S., Mikus, G., Carrà, G., Castellazzi, M., Lucii, C., Martinotti, G., Nosè, M., Ostuzzi, G., Barbui, C., \& Haefeli, W. E. (2017). Combinations of QTc-prolonging drugs: towards disentangling pharmacokinetic and pharmacodynamic effects in their potentially additive nature. Ther Adv Psychopharmacol, 7(12), 251-264. doi: $10.1177 / 2045125317721662$

Mercuro, N. J., Yen, C. F., Shim, D. J., Maher, T. R., McCoy, C. M., Zimetbaum, P. J., \& Gold, H. S. (2020). Risk of QT Interval Prolongation Associated With Use of Hydroxychloroquine With or Without Concomitant Azithromycin Among Hospitalized Patients Testing Positive for Coronavirus Disease 2019 (COVID-19). JAMA Cardiol, 5(9), 1036-1041. doi:10.1001/jamacardio.2020.1834

Moon, J., Davison, A., \& Bandy, B. (1992). Vitamin D and aluminum absorption. Cmaj, 147(9), 1308, 1313.

Moura, C. S., Acurcio, F. A., \& Belo, N. O. (2009). Drug-drug interactions associated with length of stay and cost of hospitalization. J Pharm Pharm Sci, 12(3), 266-272. doi:10.18433/j35c7z

Mukherjee, S., \& Pahan, K. (2021). Is COVID-19 Gender-sensitive? J Neuroimmune Pharmacol, 16(1), 38-47. doi:10.1007/s11481-020-09974-z

Naggar, V. F., Khalil, S. A., \& Gouda, M. W. (1978). Effect of concomitant administration of magnesium trisilicate on GI absorption of dexamethasone in humans. J Pharm Sci, 67(7), 1029-1030. doi:10.1002/jps.2600670746

Parohan, M., Yaghoubi, S., Seraji, A., Javanbakht, M. H., Sarraf, P., \& Djalali, M. (2020). Risk factors for mortality in patients with Coronavirus disease 2019 (COVID-19) infection: a systematic review and meta-analysis of observational studies. Aging Male, 23(5), 1416-1424. doi:10.1080/13685538.2020.1774748

PDPI, PERKI, PAPDI, PERDATIN, \& IDAI. (2020 ). Pedoman Tatalaksana COVID-19 (2 ed.).

Perazella, M. A. (2000). Drug-induced hyperkalemia: old culprits and new offenders. Am J Med, 109(4), 307-314. doi:10.1016/s0002-9343(00)00496-4

Pitman, S. K., Hoang, U. T. P., Wi, C. H., Alsheikh, M., Hiner, D. A., \& Percival, K. M. (2019). Revisiting Oral Fluoroquinolone and Multivalent Cation Drug-Drug Interactions: Are They Still Relevant? Antibiotics (Basel), 8(3). doi:10.3390/antibiotics8030108

Rahman, S., Singh, K., Dhingra, S., Charan, J., Sharma, P., Islam, S., Jahan, D., Iskandar, K., Samad, N., \& Haque, M. (2020). The Double Burden of the COVID-19 Pandemic and Polypharmacy on Geriatric Population - Public Health Implications. Ther Clin Risk Manag, 16, 1007-1022. doi:10.2147/tcrm.S272908

Rezaee, H., Pourkarim, F., Pourtaghi-Anvarian, S., Entezari-Maleki, T., Asvadi-Kermani, T., \& NouriVaskeh, M. (2021). Drug-drug interactions with candidate medications used for COVID-19 treatment: An overview. Pharmacol Res Perspect, 9(1), e00705. doi:10.1002/prp2.705

Schwartz, P., \& Woosley, R. (2016). Predicting the Unpredictable Drug-Induced QT Prolongation and Torsades de Pointes. Journal of the American College of Cardiology, 67(13), 1639-1650. doi:10.1016/j.jacc.2015.12.063

Shetty, V., Chowta, M. N., Chowta, K. N., Shenoy, A., Kamath, A., \& Kamath, P. (2018). Evaluation of Potential Drug-Drug Interactions with Medications Prescribed to Geriatric Patients in a Tertiary Care Hospital. J Aging Res, 2018, 5728957. doi:10.1155/2018/5728957

Shojaei, A., \& Salari, P. (2020). COVID-19 and off label use of drugs: an ethical viewpoint. DARU Journal of Pharmaceutical Sciences, 28, 789-793. doi:10.1007/s40199-020-00351-y 
196 | Kusumawardani, L.A. dkk /Jurnal Ilmiah Farmasi (Scientific Journal of Pharmacy) 17(2) AgustusDesember 2021, 182-197

Song, Y., Zhang, M., Yin, L., Wang, K., Zhou, Y., Zhou, M., \& Lu, Y. (2020). COVID-19 treatment: close to a cure? A rapid review of pharmacotherapies for the novel coronavirus (SARS-CoV-2). Int J Antimicrob Agents, 56(2), 106080. doi:10.1016/j.ijantimicag.2020.106080

WHO. (2020a). WHO Coronavirus Disease (COVID-19) Dashboard.

WHO. (2020b). Descriptive analysis of COVID-COVID - 19-related spontaneous reports from VigiBase: interim results. Retrieved from https://www.who.int/medicines/regulation/medicinessafety

Winter, I. C. (1973). Adverse reactions to spironolactone. Jama, 225(11), 1387. 